Nippon Suisan Gakkaishi $\quad$ 78(5), 1008 (2012)

\title{
シンポジウム記録＼cjkstart水産物由来健康機能成分の機能解析と利用技術開発一有効利用と次なる展開一
}

\section{II-1. 肉質向上を目的としたステロール類の 魚への強化}

\author{
長阪 玲子 \\ 東京海洋大学
}

II-1. Enrichment of sterol derivatives in fish for improving flesh quality

REIKO NAGASAKA

Department of Food Science and Technology, Graduate School of Tokyo University of Marine Science and Technology, Minato, Tokyo 108-8477, Japan

植物性ステロールなどがフェルラ酸とエステル結合し た化合物である $\gamma$-オリザノール (ORZ) は様々な生理 調節作用があることが明らかになっている。ここでは, 米糠成分に含まれる ORZを給䬣した魚類で見られた ORZ の生理調節作用について概説する。

我が国を始め, 近年の世界的な魚類養殖では, 脂質含 量の高い飼料を投与している。これはタンパク質飼料効 率の向上と経済的観点から行われているが，漁場環境の 悪化を招いているだけではなく，天然魚に比べて脂質含 量が多いという養殖魚特有の問題点に繋がる。また，不 飽和脂肪酸が多い魚油の特徵から考えても, 過剩な脂質 の蓄積は貯蔵時の脂質劣化を原因とした品質低下を加速 する。近年, 消費者は安心, 安全な食品を強く求めるよ うになってきた。したがって, これまでのような量を求 める養殖ではなく, 質の良い養殖魚が求められることは 明白である。しかし，前述したように飼料効率と経済的 な問題から現実的な対策はあまり行われておらず，肉質 向上と環境問題等の解決を兼社備えた魚類養殖の試みは 始まったばかりである。

魚類では哺乳類と比べて糖質の利用効率が悪く, 生体 活動のエネルギーとしてアミノ酸に強く依存し，その傾 向は肉食性魚種で強くなる。人間に置き換えると 2 型 糖尿病状態であるといえる。ORZには脂質代謝充進作 用があることが明らかになっていることから，1-2) 魚類 に扔いても同様の効果が期待された。そこで演者らは, ORZ による魚類の脂質代謝制御法を確立した。

ニジマスに ORZ を含有する飼料を投与し飼育すると
血糖值が有意に減少し, 脂質代謝関連酵素群の活性が増 大した。また, 糖質および脂質代謝が促進され, 結果的 にタンパク質節約効果によって約 10-20\% 程度の飼料 効率増加による体重増加が得られた。また，この ORZ の飼料効率改善効果はブリやマダイに扔いても確認され た。 ${ }^{3)}$ さらに, ORZ は哺乳類の筋肉中に蓄積されない が，ニジマス，ブリ，マダイでは，ORZ 投与によって 筋肉中に ORZ が蓄積された。3) すなわち, ORZで養殖 した魚を食べることによって糖尿病などの生活習慣病予 防効果をも期待できる。

哺乳類ではコレステロール以外のステロール類を排除 する機構が発達しているが，二ジマスの反転腸に扔いて， ORZ と植物ステロールの一つであるスティグマステ ロールの吸収が確認された。魚類では, スティグマステ ロールなどの植物性ステロールやその誘導体はコレステ ロールと同様にステロール輸送機構によって小腸上皮細 胞を介して体内に取り込まれるものと考えられた。さら に，吸収されたスティグマステロールには遊離型も検出 されたことから，哺乳類とは異なり，エステル化を伴わ ない輸送形態が存在する可能性も示唆された。

さらに貯蔵中のブリ血合肉の変色について検討したと ころ，ORZ 投与区に扔いて血合肉の変色が有意に抑え られた。4)

以上のように，穀類糠や ORZ の投与によってマダイ やブリを始めとする養殖魚の品質抢よび肉質の向上はも とより，付加価值向上も期待できる。

\section{文献}

1) Ohara K, Kiyotani $Y$, Uchida A, Nagasaka R, Maehara H, Kanemoto S, Hori M, Ushio H. Oral administration of $\gamma-$ aminobutyric acid and $\gamma$-oryzanol prevents stress-induced hypoadiponectinemia. Phytomedicine 2011; 18: 669-671.

2) Nagasaka R, Yamsaki T, Uchida A, Ohara K, Ushio H. $\gamma$ Oryzanol recovers mouse hypoadiponectinemia induced by animal fat ingestion. Phytomedicine 2011; 18: 655-660.

3) Nagasaka R, Kazama T, Ushio H, Sakamoto H, Sakamoto $\mathrm{K}$, Satoh S. Accumulation of gamma-oryzanol in teleost. Fish. Sci. 2011; 77: 431-438.

4）長阪玲子, 風間貴充, 潮 秀樹, 坂本浩志, 坂本憲一. $\gamma-$ オリザノールの添加がアスタキサンチン含有飼料によるブ リ切り身の変色抑制作用に及ぼす影響. 日水誌 2011; 77: 1101-1104. 